\title{
FREQUENCY OF HUMAN LEUKOCYTE ANTIGEN (HLA) IN PATIENTS WITH MALARIA AND IN THE GENERAL POPULATION OF HUMAITÁ COUNTY, AMAZONAS STATE, BRAZIL
}

\section{Domingos Alves Meira1, Jordão Pellegrino Júnior², Jussara Marcondes-Machado', Kimiyoski Tsuji ${ }^{3}$, Elinda Satie Matsuoka4, Elizete Haida ${ }^{4}$ e Albert Boutros EI Khoury ${ }^{4}$}

\begin{abstract}
In August 1983, 85 inhabitants of the municipality of Humaitá, Amazonas State, Brazil were studied to determine the prevalence of antigens to $H L A-A,-B,-C$ and $D R$. Thirty-eight were sick with malaria due to Plasmodium falciparum. All subjects were examined for splenomegaly, blood parasitaemia and antibodies to malaria. They constituted three groups: 1) 25 subjects native to the Amazon region who had never had malaria; 2) 38 Amazonian subjects who had malaria in the past or currently had an infection; 3) 22 patients with malaria who had acquired the infection in the Amazon Region but came from other regions of Brazil.

Blood was taken from each person, the lymphocytes were separated and typed by the test of microlymphocy totoxicity.

There was a high frequency of antigens that could not be identified in the groups studied which suggests the existence of a homozygote or phenotype not identified in the population. There was a high frequency of the phenotype Ao(W24) (44.7\%) in group 2 when compared with group 1(32\%) or group 3 (9\%). Also the individuals in group 2 showed an elevated frequency of antigen $D R_{4}(80 \%)$ when compared with group $1(36.6 \%)$ or group $3(16.6 \%)$.

These observations suggest the possibility of a genetic susceptibility to malaria among Amazonian residents and indicate a necessity for more extensive studies of the frequency of HLA antigens among inhabitants of this endemic malarial zone.

Key words: Plasmodium falciparum malaria. HLA frequency.
\end{abstract}

The relationships between AS hemoglobinopathy and natural resistance to Plasmodium falciparum malarial 2 and Duffy blood group negativity with Plasmodium vivax malaria9 111213 are well documented. In an earlier study, we reported the incidence of these factors in a population sample of Humaita County, Amazonas State, Brazil ${ }^{11}$. In that study, hemoglobin AA was found in all of the 39 Tenhairim Indians who were examined, and hemoglobin AS in only 3 of $46(2.5 \%)$ of a general population sample. In contrast, the frequency of the Fy (a-b-) phenotype was $7.1 \%$ in the Tenhairim compared with $11.5 \%$ in the general population ${ }^{3}$.

Recently, Sulzer et al ${ }^{14}$ reported a locus of hyperendemic Plasmodium vivax and Plasmodium malariae but a conspicuous absence of Plasmodium

1. Department of Infectious and Parasitic Diseases, School of Medicine, Botucatu - UNESP.

2. Department of Urology, School of Medicine, Botucatu UNESP.

3. Transplantation Immunology Center, School of Medicine, Tokai University, Japan.

4. Blood Bank, Hospital do Servidor Público do Estado de São Paulo.

Endereço para correspondência: Dr. Domingos Alves Meira, Faculdade de Medicina de Botucatu/UNESP, Caixa Postal $522-18600$ Botucatu, SP, Brasil.

Supported by a CNPq grant (PIDE - Proc. 40.3705/82).

Recebido para publicação em 7/4/86. falciparum malaria, in a primitive tribe in the Peruvian Amazon jungle. They interpreted these data to suggest that $P$. vivax and $P$. malariae have existed in the New World since pre-Columbian times. The existence of a negative phenotype for $\mathrm{Fy}(\mathrm{a}-\mathrm{b}-$ ) among the Tenhairim Indians also suggests that a natural selection for resistant individuals has occurred in areas in Brazil where malaria is endemic.

As human leukocyte antigen (HLA) typing may provide useful information regarding susceptibility to disease ${ }^{16}$, and since a relationship between certain HLA antigens and malaria has been reported ${ }^{15}$, we felt that it would be of interest to investigate the relationship of HLA-A, B, C, and, for the first time, DR antigens to malaria, among a sample of infected and non-infected inhabitants of Humaitá County.

\section{MATERIAL AND METHODS}

In August 1983, 85 subjects ( 64 males and 21 females; ages, 10 to 62 years) from urban and rural Humaitá County (see Figure 1), including 38 patients who were experiencing acute $P$. falciparum malaria were surveyed. Each study participant provided a social history, a medical history documenting previous malarial attacks, and was clinically examined for evidence of splenic enlargement ${ }^{7}$. Blood samples from each subject were examined microscopically for malarial 
Meira DA, Pellegrino Jr J, Marcondes-Machado J, Tsuji K, Matsuoka ES, Haida E, El Khoury AB. Frequency of human leukocyte antigen (HLA) in patients with malaria and in the general population of Humaita county, Amazonas State, Brazil. Revista da Sociedade Brasileira de Medicina Tropical 20: 153-158, Jul-Set, 1987.

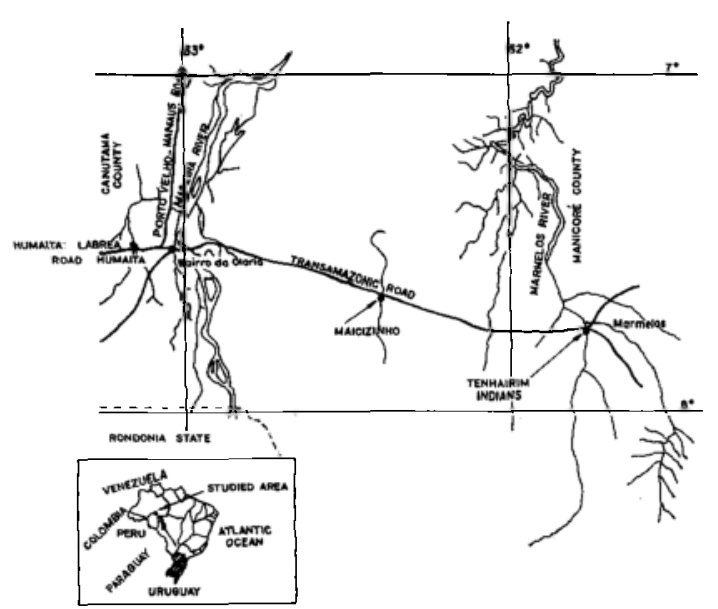

Figure 1 - Map showing location of Humaita County.

parasites, tested by passive hemagglutination for the presence of malarial antibodies 8 , and tested by lymphocytotoxity for HLA antigens. ${ }^{10}$

Based on their social, medical histories, and clinical evaluations, the subjects were classified as follows:

Group I(Control Group): A group composed of 25 subjects who were native to the Amazon region, had no history of malaria attacks, had impalpable spleens, and had no peripheral blood parasites or malarial antibodies.

Group II: A second group composed of 38 subjects who were native from the Amazon region and who had history of malaria plus: (a) presented with active malaria $(n=17)$ or $(b)$ were positive for malarial antibodies $(\mathrm{n}=21)$.

Group III: A third group was composed of 22 subjects who had emmigrated to the Amazon region from southern Brazil (ie, were not native-born) and who presented with active $P$. falciparum malaria.

Blood samples were drawn from each subject and the lymphocytes separated by Ficoll-Hypaque density gradient centrifugation. Isolated lymphocytes were stored in liquid nitrogen ${ }^{5}$ prior to antigen typing for HLA-A, B, and C antigens. Lymphocytes from some subjects in each group were further separated into $B$ and $T$ subpopulations ${ }^{4}$ before testing for $\mathrm{DR}$ antigens.

Histocompatibility testing was performed using the microlymphocytotoxicity test ${ }^{10}$. Forty antisera were available to determine $15 \mathrm{HLA}-\mathrm{A}$ locus antigens, 70 antisera to determine 21 HLA-B locus antigens, twelve sera to determine seven HLA-C locus antigens, and 36 sera to type nine HLA-DR locus antigens ( $\mathrm{Ta}^{-}$ ble 1). These antisera were provided by Professor Kimiyoshi Tsuji, who is a member of the workshop of the International Council of HLA typing.

Table 1 - Number of selected cytotoxic sera used to type Humaita inhabitants and malaria patients and their $H L A$ specificities.

\begin{tabular}{|c|c|c|c|c|c|c|c|}
\hline $\begin{array}{c}H L A \\
\text { Locus } A\end{array}$ & $\begin{array}{c}N .^{\circ} \text { of sera } \\
\text { used }\end{array}$ & $\begin{array}{r}H L A \\
\text { Locus } B\end{array}$ & $\begin{array}{c}\text { No of sera } \\
\text { used }\end{array}$ & $\begin{array}{c}\text { HLA } \\
\text { Locus } C w\end{array}$ & $\begin{array}{c}\text { No of sera } \\
\text { used }\end{array}$ & $\begin{array}{c}H L A \\
\text { Locus } D R\end{array}$ & $\begin{array}{c}\text { No of sera } \\
\text { used }\end{array}$ \\
\hline $\begin{array}{l}\text { HLA - } A_{1} \\
\text { HLA - A2 } \\
\text { HLA - A3 } \\
\text { HLA - A9 } \\
\text { HLA - A9(w23) } \\
\text { HLA - A9(w24) } \\
\text { HLA - A10 } \\
\text { HLA - A11 } \\
\text { HLA - A19 } \\
\text { HLA - A19(w29) } \\
\text { HLA - A19(w30) } \\
\text { HLA - A19(w31) } \\
\text { HLA - A19(w32) } \\
\text { HLA - A19(w33) } \\
\text { HLA - A28 }\end{array}$ & $\begin{array}{l}3 \\
4 \\
2 \\
2 \\
1 \\
1 \\
4 \\
3 \\
3 \\
4 \\
4 \\
4 \\
1 \\
1 \\
3\end{array}$ & 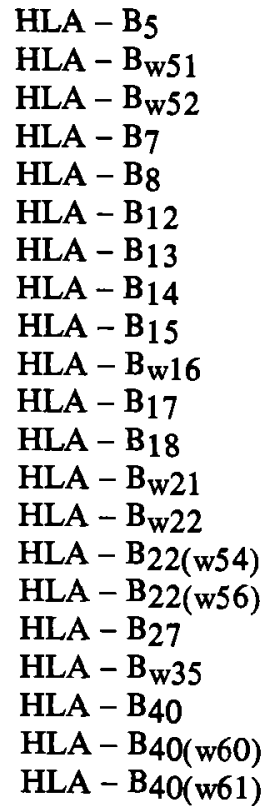 & $\begin{array}{l}4 \\
3 \\
2 \\
7 \\
4 \\
5 \\
5 \\
3 \\
3 \\
3 \\
3 \\
2 \\
4 \\
3 \\
3 \\
1 \\
3 \\
3 \\
5 \\
2 \\
2\end{array}$ & $\begin{array}{l}\text { HLA }-C_{w 1} \\
\text { HLA }-C_{w 2} \\
\text { HLA }-C_{w 3} \\
\text { HLA }-C_{w 4} \\
\text { HLA - } C_{w 5} \\
\text { HLA - } C_{w 6} \\
\text { HLA - C } \\
\text { HLA - C } 78\end{array}$ & $\begin{array}{l}3 \\
1 \\
3 \\
2 \\
- \\
1 \\
1 \\
1\end{array}$ & 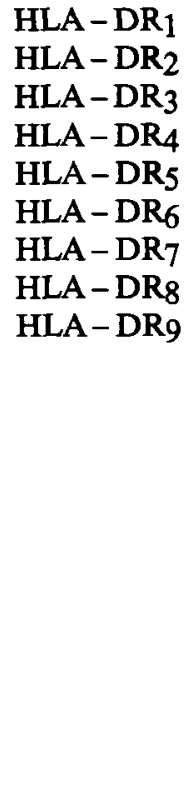 & $\begin{array}{l}4 \\
6 \\
3 \\
6 \\
2 \\
1 \\
4 \\
4 \\
6\end{array}$ \\
\hline
\end{tabular}


Meira DA, Pellegrino Jr J, Marcondes-Machado J, Tsuji K, Matsuoka ES, Haida E, El Khoury AB. Frequency of human leukocyte antigen (HLA) in patients with malaria and in the general population of Humaitá county, Amazonas State, Brazil. Revista da Sociedade Brasileira de Medicina Tropical 20: 153-158, Jul-Set, 1987.

Results were analyzed by the Chi square test ${ }^{17}$. A $95 \%$ confidence limit was established.

\section{RESULTS}

The phenotypic and genetic frequencies of HLA-A, B, C and DR antigens found in all study groups are show in Table 2. In Group II subjects (infected residents), the $\mathrm{A} 9$ (W 24) antigen was found in 17 of 38 subjects $(44.7 \%)$. A comparison among the three groups regarding $\mathrm{A}, \mathrm{B}$ and $\mathrm{C}$ antigens indicates a higher phenotypic frequency of the $A_{9}$ (W 24) antigen in Group II (44.7\%) than in Group III (9\%). This difference is statistically significant $(p<0.05)$. There were no other statistically significant differences in phenotypic frequencies among the study group at the A, B, or C loci. While not statistically significant, the frequency of $\mathrm{Ag}_{9}(\mathrm{~W} 24)$ in Group I subjects was $32 \%$. Some subjects from each group were tested for DR antigens (Table 2). A statistically significant differen-

Table 2 - Phenotype and gene frequency in HLA antigens of 25 normal Amazonian individuals (Group I); 38 Amazonian malaria patients (Group II); and 22 non Amazonian patients with malaria (Group III)

\begin{tabular}{|c|c|c|c|c|c|c|c|c|c|}
\hline \multirow{2}{*}{$\begin{array}{r}H L A \\
\text { Antigens }\end{array}$} & \multicolumn{3}{|c|}{ Group I } & \multicolumn{3}{|c|}{ Group II } & \multicolumn{3}{|c|}{ Group III } \\
\hline & $\begin{array}{l}\text { No of } \\
\text { Cases }\end{array}$ & $\begin{array}{r}\text { Phenot. } \\
\text { freq. }\end{array}$ & $\begin{array}{l}\text { Gene } \\
\text { freq. }\end{array}$ & $\begin{array}{l}\text { No of } \\
\text { Cases }\end{array}$ & $\begin{array}{r}\text { Phenot. } \\
\text { freq. }\end{array}$ & $\begin{array}{l}\text { Gene } \\
\text { freq. }\end{array}$ & $\begin{array}{l}\text { No of } \\
\text { Cases }\end{array}$ & $\begin{array}{l}\text { Phenot. } \\
\text { freq. }\end{array}$ & $\begin{array}{l}\text { Gene } \\
\text { freq. }\end{array}$ \\
\hline Locus A & Total $=25$ & $\%$ & & Total $=38$ & $\%$ & & otal $=22$ & $\%$ & \\
\hline $\mathrm{A}_{1}$ & 2 & 8.0 & 0.040 & 3 & 7.9 & 0.040 & 1 & 4.5 & 0.022 \\
\hline $\mathrm{A}_{2}$ & 12 & 48.0 & 0.278 & 13 & 34.2 & 0.188 & 12 & 54.5 & 0.320 \\
\hline $\mathbf{A}_{3}$ & 5 & 20.0 & 0.105 & 6 & 15.8 & 0.082 & 3 & 13.6 & 0.070 \\
\hline $\left.\mathrm{A}_{9(\mathrm{w}} 23\right)$ & 0 & - & - & 3 & 7.9 & 0.040 & 2 & 9.0 & 0.046 \\
\hline A9(w24) & 8 & 32.0 & 0.175 & $17 \uparrow$ & 44.7 & 0.256 & 2 & 9.0 & 0.046 \\
\hline $\mathbf{A}_{10}$ & 3 & 12.0 & 0.061 & 5 & 13.1 & 0.068 & 2 & 9.0 & 0.046 \\
\hline $\mathrm{A}_{11}$ & 5 & 20.0 & 0.105 & 1 & 2.6 & 0.013 & 6 & 27.2 & 0.147 \\
\hline A19 & 4 & 16.0 & 0.083 & 8 & 21.0 & 0.114 & 2 & 9.0 & 0.046 \\
\hline$A_{19}(w 29)$ & 3 & 12.0 & 0.061 & 4 & 10.5 & 0.054 & 2 & 9.0 & 0.046 \\
\hline $\mathrm{A}_{19}(\mathrm{w} 30)$ & 0 & - & - & 3 & 7.9 & 0.040 & 0 & - & - \\
\hline $\mathrm{A}_{19(w 31)}$ & 0 & - & - & 2 & 5.3 & 0.026 & 1 & 4.5 & 0.022 \\
\hline$A_{19}(w 33)$ & 1 & 4.0 & 0.020 & 2 & 5.3 & 0.026 & 1 & 4.5 & 0.022 \\
\hline A 28 & 2 & 8.0 & 0.040 & 3 & 7.9 & 0.040 & 2 & 9.0 & 0.046 \\
\hline Blank & 5 & - & 0.105 & 6 & - & 0.082 & 8 & - & 0.202 \\
\hline
\end{tabular}

\begin{tabular}{|c|c|c|c|c|c|c|c|c|c|}
\hline Locus B & Total $=25$ & & & $\mathrm{tal}=\mathbf{3 8}$ & & & $\mathrm{al}=$ & & \\
\hline B5 & 0 & - & - & 0 & - & - & 0 & - & - \\
\hline $\mathrm{B}_{\mathrm{W} 51}$ & 8 & 32.0 & 0.175 & 9 & 23.7 & 0.126 & 6 & 27.2 & 0.147 \\
\hline $\mathrm{B}_{\mathrm{w} 52}$ & 1 & 4.0 & 0.020 & 4 & 10.5 & 0.054 & 1 & 4.5 & 0.022 \\
\hline B7 & 4 & 16.0 & 0.083 & 4 & 10.5 & 0.054 & 4 & 18.1 & 0.095 \\
\hline $\mathrm{B}_{8}$ & 1 & 4.0 & 0.020 & 1 & 2.6 & 0.013 & 2 & 9.0 & 0.046 \\
\hline $\mathrm{B}_{12}$ & 6 & 24.0 & 0.128 & 3 & 7.8 & 0.040 & 6 & 27.2 & 0.147 \\
\hline$B_{13}$ & 1 & 4.0 & 0.620 & 4 & 10.5 & 0.054 & 1 & 4.5 & 0.022 \\
\hline$B_{14}$ & 2 & 8.0 & 0.040 & 3 & 7.8 & 0.040 & 4 & 18.1 & 0.095 \\
\hline$B_{15}$ & 6 & 24.0 & 0.128 & 4 & 10.5 & 0.054 & 2 & 9.0 & 0.046 \\
\hline $\mathrm{B}_{16}$ & 2 & 8.0 & 0.040 & 6 & 15.7 & 0.082 & 0 & - & - \\
\hline$B_{17}$ & 3 & 12.0 & 0.061 & 6 & 15.7 & 0.082 & 2 & 9.0 & 0.046 \\
\hline$B_{18}$ & 0 & - & - & 1 & 2.6 & 0.013 & 0 & - & - \\
\hline$B_{21}$ & 0 & - & - & 4 & 10.5 & 0.054 & 2 & 9.0 & 0.046 \\
\hline$B_{22(w 54)}$ & 0 & - & - & 1 & 2.6 & 0.013 & 1 & 4.5 & 0.022 \\
\hline $\mathrm{B}_{22(\mathrm{w} 56)}$ & 1 & 4.0 & 0.020 & 1 & 2.6 & 0.013 & 2 & 9.0 & 0.046 \\
\hline B27 & 1 & 4.0 & 0.020 & 0 & - & - & 0 & - & - \\
\hline$B_{w 35}$ & 5 & 20.0 & 0.105 & 14 & 36.8 & 0.205 & 5 & 22.7 & 0.120 \\
\hline B40 & 0 & - & - & 0 & - & - & 1 & 4.5 & 0.022 \\
\hline$B_{40}(w 60)$ & 1 & 4.0 & 0.020 & 4 & 10.5 & 0.054 & 0 & - & - \\
\hline B40(w61) & 3 & 12.0 & 0.061 & 4 & 10.5 & 0.054 & 3 & 13.6 & 0.070 \\
\hline Blank & 5 & - & 0.105 & 3 & - & 0.040 & 2 & - & $\begin{array}{r}0.046 \\
\text { ontinue) }\end{array}$ \\
\hline
\end{tabular}


Meira DA, Pellegrino Jr J, Marcondes-Machado J, Tsuji K, Matsuoka ES, Haida E, El Khoury AB. Frequency of human leukocyte antigen (HLA) in patients with malaria and in the general population of Humaitá county, Amazonas State, Brazil. Revista da Sociedade Brasileira de Medicina Tropical 20: 153-158, Jul-Set, 1987.

(Continuation)

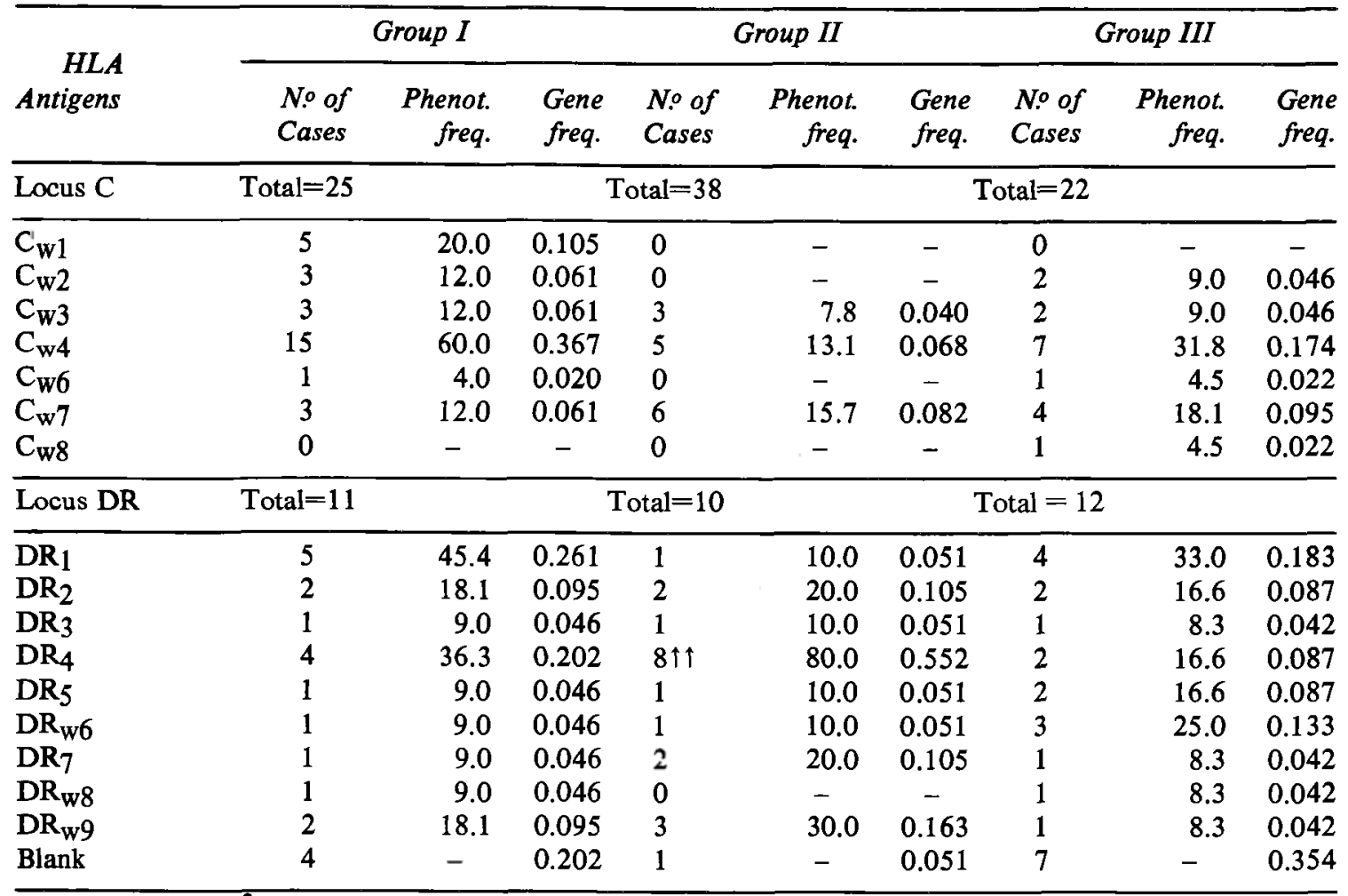

$\uparrow=$ High frequency $\left(\mathrm{X}^{2}=4.318 \mathrm{p}<0.05\right.$ II $>$ III $)$

$\uparrow \uparrow=$ High frequency $\left(\mathrm{X}^{2}=4.072 \mathrm{p}<0.05 \mathrm{II}>\mathrm{I} ; \mathrm{X}^{2}=8.824 \mathrm{p}<0.005 \mathrm{II}>\mathrm{III}\right)$

ce in phenotypic frequency for the $\mathrm{DR}_{4}$ antigen was observed between Group II $(80 \%)$ and Group I $(36,3 \%) ; p<0.05)$ and Group III $(16,6 \% ; p<0.005)$. A higher incidence of blank alleles was found in the studied groups.

\section{DISCUSSION}

Genetically homogeneous native Indian tribes can still be found in scattered settlements throughout the Amazon region, and it is likely that their ancestors contributed greatly to the genetic make up of the current indigenous population ${ }^{6}$. The heterogeneous gene pool of the general population of this region reflects contributions from Portuguese and native African immigrants. The recent wave of immigration into the Amazon region of residents from southern Brazil, due to governmental colonization projects and the construction of the Transamazon highway, will further alter the genetic composition of the general population of the Amazon region. These immigrants are primarily of Caucasian stock.

The HLA system represents a complex of genes that have an important role in the maintenance of life and in the defense mechanisms of the body ${ }^{16}$. Surveys conducted to determine the prevalence of these factors among individuals infected with malaria may have important sociologic and epidemiologic implications. Malaria is endemic throughout the Amazon region, and its prevalence has been increasing since 1970 . One explanation for this increase may be the changing racial composition of the inhabitants of this region and the introduction of host suceptibility factors.

We found a high frequency of blank alleles in the studied groups. Jobim et al $^{6}$ also reported a high frequency of blank alleles when typing the $A$ and $B$ loci of the Tukuna Indians, a tribe which inhabits part of the Amazon River Basin near border of Peru and Colombia. They interpreted this observation to indicate a high incidence of homozygous cells for certain antigens or the presence of as unidentified antigens in this population. Similarly, Tsuji ${ }^{16}$ reported high values for blank alleles for A and B antigens among new-born Japanese, with a tendency toward increasing heterozygocity with increasing age. Homozygocity is one consequence of prolonged intergroup breeding. Tsuji suggest that the increased heterozygocity seen in older Japanese reflects the operation of natural selection in favor of disease-free individuals.

Jobim et al $^{6}$ also reported a phenotypic frequency of $78.7 \%$ for HLA-A (w24) antigen among the Tukunas; this is one of the highest rates reported in Indians of the Americas. As all cells with HLA-(w24) also cross react with HLA-A9, it is likely that the high 
Meira DA, Pellegnino Jr J, Marcondes-Machado J, Tsuji K, Matsuoka ES, Haida E, El Khoury AB. Frequency of human leukocyte antigen (HLA) in patients with malaria and in the general population of Humaitá county, Amazonas State, Brazil. Revista da Sociedade Brasileira de Medicina Tropical 20: 153-158, Jul-Set, 1987.

frequency of $A_{9(w 24)}$ seen in Group I natives in our studies reflects the genetic contribution of the Indians to this population.

More importantly, the statistically significant differences in the phenotypic frequency of the $\mathrm{DR}_{4}$ antigen between Group II (ie, native-born infected individuals) and Group I and III suggest that a high incidence of this antigen may predispose individuals who are positive for this antigen to infection with malaria. To our knowledge, this is the first observed relationship of the DR allele and the susceptibility to infection with malaria.

Although our population sample was small, this preliminary survey adds further evidence for an association between the geneological origin of patients, HLA antigens, and a predisposition for malaria. This preliminary finding warrants a larger study using larger population samples from additional regions of the Amazon. If it were possible to determine the phenotypes of specific individuals for those antigens that may predispose them to infection with malaria, these persons could be warned of the potential risk of contracting malaria in areas where the disease is endemic.

\section{RESUMO}

Em agosto de 1983 foram observados 85 habitantes do Município de Humaitá, Estado do Amazonas, Brasil, com a finalidade de estudar a prevaléncia dos antígenos de $H L A-A,-B,-C$ e $D R$, dentre os quais 38 eram doentes com malária causada pelo Plasmodium falciparum. Todos eles foram examinados para avaliação de esplenomegalia, exame parasitológico de sangue e pesquisa de anticorpos de malária. Foram constituídos três grupos: (I) 25 individuos nascidos na região Amazônica que nunca tiveram malária; (II) 38 individuos naturais da Amazônia que tinham sido tratados de malária no passado, ou que estavam tendo malária atual, e(III) 22 doentes com malária que contraíram na Amazônia e eram procedentes de outras regiões do Brasil. Foram colhidas amostras de sangue de cada um deles, separados os linfócitos $e$ os antígenos de HLA foram tipados pelo teste de microlinfocitotoxidade.

Houve elevada freqüência de antígenos não identificados, nos grupos estudados, o que sugere ou a existência de homozigoze, ou fenótipo não identificado nessa população. Houve alta freqüência fenotípica de antígeno de $A_{9}(W 24)$ (44,7\%) no Grupo II, quando comparado ao Grupo I (32\%) ou Grupo III (9\%). Os indivíduos do Grupo II mostraram também elevada freqüência do antígeno $\mathrm{DR}_{4}(80 \%)$ quando comparado ao Grupo I (36,3\%) ou Grupo III (16,6\%).

Essas observações sugerem a possibilidade de suscetibilidade genética à malária entre os nativos da Amazônia e indicam a necessidade da realização de inquéritos mais extensos sobre a freqüência de antígenos de HLA em habitantes de zona endêmica de malária.

Palavras chaves: Malária. Plasmodium falciparum. Prevalência de HLA.

\section{ACKNOWLEDGEMENTS}

We wish to thank the Fundação Projeto Rondon, Diretoria de Campus Avançado and SUCAM Humaitá.

\section{REFERENCES}

1. Allison AC. Protection afforded by sickle cell trait against subtertian malarial infection. British Medical Journal 1:290-294, 1954.

2. Brain P. Advantage in health for heterozygotes. South African Medical Journal 26:925-928, 1952.

3. Colauto EMR, Barraviera B, Meira DA, Matsubara LS, Pellegrino-Júnior J, Machado PEA, Sogayar R, Barboza AF, Silva EA, Colauto R, Pirola JAG, Mendes RP. Malária no município de Humaitá, Estado do Amazonas. XII - Freqüência de fatores de resistência eritrocitária na população geral e em doentes: hemoglobina $\mathbf{S}$ e sistema sangüineo Duffy. Revista do Instituto de Medicina Tropical São Paulo, 23 (Supl. 5): 72-78, 1981.

4. Danilovs J, Terasaki PI, Park MS, Ayoub G. B. lymphocyte isolation by thrombin-nylon wool. 8 th International Histocompatibility Workshop and Conference. Newsletter 6, December, 1978.

5. Hors J, Preud'Homme JL, Toulze-Zapateria MT, Guillet-Bigot J, Roy PJ, Dausset J. A simplified method for freezing lymphocytes in nitrogen vapors. Transplantation 15:417-419, 1973.

6. Jobim LF, Moura NC, Persolla LB, Trachtenberg A, Walford R, Mendes NF. HLA antigens in Tukuna Indians. American Journal of Physiology and Antropology 56:285-290, 1981 .

7. Meira DA, Curi PR, Barraviera B. Malaria in Humaitá County, Amazonas State, Brazil. XXIX - Some comparative aspects in 1976,1979 and 1983. Proceedings of IV Japan-Brazil Symposium on Science and Technology 2:136-143, 1984.

8. Meira DA, Marcondes J, Mendes RP, El-Khoury AB, Curi V, Rui P. Malaria in Humaitá County, Amazonas State, Brazil. XXXV - Inquiry into the epidemiology of the general population using passive hemagglutination. Proceedings of IV Japan-Brazil Symposium on Science and Technology 2:148-151, 1984.

9. Miller LH, Mason SJ, Dvorak JA, Mc Ginnis MH, Rothman JK. Erythrocyte receptors for (Plasmodium knowlesi) malaria: Duffy blood group determinants. Science 189:561-563, 1975.

10. Ray JG, Hare DB, Pedersen PD, Mullally DI. Manual of tissue typing techniques. DHEW publication No (NIH) 74-545. National Institutes of Health Bethesda, 1976.

11. Sanger R, Race RR, Jack J. The Duffy blood groups of New York negros. The phenotype Fy (a-b-). British Journal of Haematology. 1:370-374, 1955.

12. Simonneau M, Machali D, Penalba CH, Couland JP, Saimot G. Le group sanguin Duffy chez le migrants 
Meira DA, Pellegrino Jr J, Marcondes-Machado J, Tsuji K, Matsuoka ES, Haida E, El Khoury AB. Frequency of human leukocyte antigen (HLA) in patients with malaria and in the general population of Humaitá county, Amazonas State, Brazil. Revista da Sociedade Brasileira de Medicina Tropical 20: 153-158, Jul-Set, 1987.

d'Afrique francophone. Bulletin Société Pathologie Exotique 76:470-475, 1983.

13. Spencer HC, Miller LH, Colliens WE, Knud-Hansen C, Mc Ginnis MH, Sniroishi T, Lobos RA, Feldman RA. The Duffy blood group and resistence to Plasmodium vivax in Honduras. American Journal of Tropical Medicine and Hygiene 27:664-670, 1978.

14. Sulzer AJ, Sulzer KR, Cantella RA, Colichon A, Gleason NN, Walls KW. Study of coinciding foci of malaria and leptospirosis in the Peruvian Amazon area. Transactions of the Royal Society of Tropical Medicine and Hygiene 72:76-83, 1978 .
15. Sy NE, Long GW, Alcantara AK, Ranoa CP, Cross JH. HLA antigens and malaria at San Lazaro Hospital Manila, Philipines. Southeast Asian Journal of Tropical Medicine and Public Health 15:1-6, 1984.

16. Tsuji K. Human MHC and the characteristics of HLA in the Japanese. Asian Medicine Journal 24:336-355, 1981

17. Tsuji K, Nose Y, Inouye H. Komori K, Yamamura M. HLA - D/DR linked immune response to Candida allergen: an in vivo and vitro study in Japanese. Tokai Journal of Experimental and Clinical Medicine 6:113$120,1981$. 